\title{
Video Musik Sabyan Gambus "Atouna El Toufoule" Studi Analisis Semiotika Charles Sanders Peirce
}

\author{
Erna Kurniawati \\ Program Studi Magister Komunikasi dan Penyiaran Islam \\ Fakultas Dakwah dan Komunikasi UIN Sunan Kalijaga Yoyakarta \\ Email : Ernhadena@gmail.com
}

\begin{abstract}
The purpose of this analysis is to give meaning to the signs in the music video using Charles Sanders Pierce's semiotic analysis method. Based on the analysis of data obtained from internet sources and those in the Atouna El Toufoule Sabyan gambus music video, it shows that this media is able to provide a clear picture of the events that occurred in Palestine, with various images in the video that have been able to represent the sadness felt by Palestinian people and have meanings that can be understood by the public by looking at this video. Although in this video only wants to describe the conditions of children in Palestine by not displaying the real attitude or violent treatment carried out by the state of Israel to the Palestinians, what is shown is post war.
\end{abstract}

Keywords: Atouna El Toufoule, Sabyan Gambus, Charles Sanders peirce

\begin{abstract}
Abstrak
Tujuan dari analisis ini adalah memberikan pemaknaan terhadap tanda-tanda yang ada pada video musik tersebut dengan menggunakan metode analisis semiotika Charles Sanders Pierce.Berdasarkan analisis data yang diperoleh dari sumber internet dan yang ada pada video musik Atouna El Toufoule Sabyan gambus, menunjukan bahwa media ini mampu memberikan gambaran jelas mengenai peristiwa yang terjadi di Palestina, dengan berbagai gambar-gambar dalam video yang sudah mampu mewakili kesedihan yang dirasakan oleh masyarakat Palestina serta memiliki makna-makna yang bisa dipahami oleh masyarakat dengan cara melihat video ini. Meskipun dalam video ini hanya ingin menggambarkan kondisi-kondisi anak-anak yang ada di Palestina dengan tidak menampilkan sikap atau perlakuan kekerasan secara nyata yang dilakukan oleh negara Israel kepada Palestina, namun yang ditampilkan adalah pasca peperangan.
\end{abstract}

Kata Kunci : Atouna El Toufoule, Charles Sanders peirce

Al-Munzir Vol. 12. No. 1 Mei 2019 


\section{A. Pendahuluan}

Perkembangan dunia industri media massa, baik itu yang dimiliki oleh media mainstream, media cetak, media elektronik maupun new media, selalu memiliki konten-konten menarik untuk disajikan bagi para penikmat media. Dengan adanya berbagai ragam konten, baik itu mengandung hiburan, pendidikan serta informasi yang ada dalam sebuah media adalah bentuk usaha dari media untuk menguasai konsumen atau mengkomersilkan suatu konten yang sudah disajikan agar laku di mayarakat. Namun di balik itu semua, konten-konten tersebut memiliki makna dan ideologi-ideologi tersendiri yang sudah dikemas kemudian disampaikan dan disebarluaskan kepada masyarakat, melalui mediamedia yang ada.

Dampak globalisasi dan kemajuan teknologi telah menciptakan interkoneksi antar manusia. Hal ini ditandai dengan adanya perubahan gaya hidup, perilaku kritis dan kepekaan tinggi. Pola penciptaan nilai dalam industri kreatif yang meliputi sektor kreasi, produksi, distribusi dan komersialiasi pun berubah. Tingginya kreativitas sumber daya manusia yang ditawarkan industri ini menjadi landasan untuk menuju keadaan yang lebih baik. Teknologi infomasi dan komunikasi yang kian akrab dengan pengguna, semakin mendorong munculnya ragam kreativitas tersebut. Melalui internet, berbagai hal tak terduga memberi harapan-harapan baru yang bahkan tak terpikir sedikitpun di era konvensional.

Sebagai sumber kebudayaan, rekaman suara telah berperan sebagai katalis perubahan dan cerminan nilai-nilai kebudayaan. Sebagai institusi bisnis, musik rekaman berkembang menjadi industri yang sangat menguntungkan dan memiliki masa depan ekonomis yang cerah. (Arif Kusumawardhani, 2014:121). Namun di lain pihak rekaman musik yang ada di era konvensional, mulai bergeser keberadaannya dengan adanya musik digital yang ada pada era 2.0 dalam konteks yang lebih luas, sehingga netlabel bisa masuk dalam kategori konvergensi media. Konvergensi media ini tidak hanya memperlihatkan perkembangan teknologi yang kian masif, namun juga mengubah hubungan antara teknologi, industri, pasar, gaya hidup dan khalayak. Konvergensi memberikan kesempatan baru kepada publik untuk memperluas pilihan akses media sesuai selera mereka, yang bukan hanya menampilkan audio tapi juga visual atau yang biasa disebut video musik, mampu menghipnotis pencinta musik untuk lebih mendalami makna dalam sebuah lirik berupa audio maupun gambar visual yang sedang ditonton. Al-Munzir Vol. 12. No. 1 Mei 2019 
Sehingga antara media dan penonton atau audien sama-sama memiliki keuntungan atau simbiosis mutualis, baik hanya untuk sekedar menikmati sebagai hiburan, teman di saat bosan, teman di saat sedang galau, maupun menjadikannya sebagai penyemangat dalam belajar, atau mendengarkan lagu sebagai bentuk perwakilan kondisi perasaanya saat ini, bahkan ada sebagian lirik dari sebuah video musik diciptakan karena terinspirasi dari kisah nyata yang terjadi di sekelilingnya maupun dari cerita fiksi dan musik di sini memiliki beberapa genre, mulai dari pop, rock, dangdut, hip hip, rege, gambus dan lain sebagainya.

Selain itu, dalam penelitian ini hanya akan mengfokuskan pada genre religi musik gambus dengan kemasan modern yang dibawakan oleh grup musik Sabyan Gambus. Grup musik yang awalnya terdiri dari 2 orang yaitu penyanyi (Nissa) dan pemain keyboard (Ahmad Fairuz), namun sekarang sudah memiliki tambahan 4 personel di antaranya Sofwan Yusuf (Perkusi), Kamal (Darbuka) Tubagus Syaifulloh (Biola atau gambus) dan Anisa Rahma (Dukungan Vokal). Grup gambus ini sendiri berdiri sejak 27 Januari 2015, (http://tirto.id, 09 Juni 2018), namun baru ditahun ke-3 dilengkapi oleh ke-6 personel. Awal kemunculannya dalam merintis karir lewat media sosial dengan mencover beberapa lagu-lagu bergenre religi seperti Ya Habibal Qolbi, Rohman Ya Rohman, Ya Asyiqol, Ya Jamalu, Qomarun, Deen Assalam, Law Kana Bainanal Habib, dan Atouna El Toufoule (beri kami masa kecil). Kemudian Sabyan gambus merilis single sendiri yang terdiri dari tiga lagu Ya Maulana, Allahumma Labbaik, El Oum (Ibu) dan terakhir adalah Syukan Lillah.

Dengan banyaknya judul lagu yang dimiliki Sabyan Gambus, maka peneliti hanya akan menganalisis serta mengfokuskan pada 1 lagu yaitu Atouna El Toufoule (beri kami masa kecil). Sebuah cerita nyata yang dikisahkan atau digambarkan dalam video musik Sabyan Gambus mengenai Negeri Palestina yang sedang mengalami kesedihan akibat serangan yang dilancarkan oleh Pihak Israel. Adapun tujuan dari analisis ini adalah memberikan pemaknaan terhadap tandatanda yang ada pada video musik tersebut dengan menggunakan analisis semiotika Charles Sanders Pierce.

\section{B. Metode Penelitian}

Penelitian ini menggunakan teori analisis semiotika Charles Sanders Pierce, yang membagi klarisifikasi tanda berdasarkan ground, object, interpretant. (Alex Al-Munzir Vol. 12. No. 1 Mei 2019 
Sobur, 2006:41) Dengan teori tersebut, peneliti akan menganalisis scene-scene dalam video grup musik Sabyan Gambus cover lagu yang berjudul Atouna El Toufoule (beri kami masa kecil), dengan durasi 5 menit 37 detik, yang mengisahkan tentang cuplikan kisah anak-anak kecil yang berada di Timur Tengah dan menjadi korban serangan di Palastina dan Suriah, dengan jumlah penonton dalam video ini lebih dari 11 juta viewer. (http://www.aceh.tribunnews.com, 26 Desember 2018) Dalam hal ini peneliti mencoba akan memberikan pemaknaan menggunakan analisis semiotika terhadap kejadian-kejadian yang terjadi di Palestina dan Suriah melalui tanda-tanda yang divisualisasikan dalam video musik yang berjudul Atouna El Toufoule dengan teori segitiga Charles Sanders Pierce, sehingga akan terlihat makna-makna apa saja yang dimunculkan darti tanda-tanda tersebut.

\section{Hasil dan Pembahasan}

\section{C.1.Sekilas Mengenai Musik Gambus dan Grup Musik Sabyan Gambus pada Lagu "Atouna EI Toufoule"}

Musik adalah sebuah keajaiban yang mampu memberikan warna tersendiri bagi seseorang yang mendengarkan maupun yang menciptakan sebuah lagu, ada sebuah istilah yang mengatakan bahwa music is magic, dikenal pada era dewasa ini. Sebab musik mampu membawa seseorang untuk terlibat dan ikut merasakan kesedihan maupun kebahagiaan yang coba dibangun pada sebuah lirik musik dan memang pada dasarnya sebuah lirik diciptakan bukan hanya sekedar cipta, karya dan rasa, namun ada sisi lain yang coba dibangun dalam sebuah lantunan musik disertai lirik. Terkadang lirik yang ditulis adalah kisah nyata, baik itu mengenai percintaan, kesedihan, kebahagiaan, ataupun kisah duka akibat peperangan, perjuangan, mengenai pendidikan, religi dan lain sebagainya. Ini adalah gambaran musik secara umum. Namun jika berbicara mengenai musik gambus maka kita berbicara sejarah dari musik itu sendiri.

Seni musik gambus merupakan salah satu alat musik yang dimainkan dengan cara dipetik. Alat musik ini idetik dengan nyanyian yang bernafaskan Islam. Dalam mengiringi penyanyi, alat musik ini juga diiringi dengan alat musik lain. Seperti marawis untuk memperindah irama nyanyian. (Titik Oktia M, 2010:41) Musik gambus merupakan akulturasi dari musik melayu dengan musik Arab. Akulturasi atau acculturation atau culture contact adalah proses sosial yang Al-Munzir Vol. 12. No. 1 Mei 2019 
timbul bila suatu kelompok manusia dengan suatu kebudayaan tertentu dihadapkan dengan unsur-unsur dari suatu kebudayaan asing dengan sedemikian rupa, sehingga unsur-unsur kebudayaan asing itu lambat laun diterima dan diolah ke dalam kebudayaan sendiri tanpa menyebabkan hilangnya kepribadian itu sendiri. (Koentjaraningrat, 2009:202)

Irama Melayu merupakan salah satu genre yang pada mulanya dikembangkan di daerah Melayu, yaitu kedua belah pantai Sumatra (pantai sebelah barat dan timur) dan Tanah Semenanjung. Di pantai sebelah barat Sumatra, suatu daerah tempat musik Melayu berkembang, musik ini memperoleh corak yang lebih khusus yaitu Gamat. Sementara itu, di pantai sebelah timur Sumatra khususnya di daerah Deli dan Tanah semenanjung, musik ini dikembangkan pula sehingga terkenal dengan nama musik Melayu Deli. Ciri khas musik Melayu Deli ini adalah aspek perlukisnya, terutama tingkahan bunyi kendang. Selain itu, unsur penting dalam musik Melayu Deli ini adalah adanya akordeon dan biola yang dimainkan oleh sejumlah pemain. Diperkirakan bawah ketika etnis melayu bermigrasi ke pulau Jawa pada awal periode kolonial, mereka juga membawa tradisi musikalnya yang belakangan terkenal dengan sebutan irama melayu Jakarta atau Betawi. Irama melayu ini, di samping melanjutkan musik tradisi Melayu Deli juga mengembangkan kekhususan tersendiri hingga musik ini lebih dinamis dan reseptif terhadap anasir baru. Ada beberapa pendapat tentang munculnya musik gambus di Nusantara, dikemukakan oleh Anis Mohd N, Md yang sudah diterjemahkan ke dalam bahasa Indonesia yaitu : "Ada berbagai teori tentang bagaimana gambus Melayu dan gambus Hadramaut tiba di Kepulauan Melayu Nusantara. Salah satu hipotesis mengatakan bahwa kedatangan gambus dibawa oleh Arab ketika Islamisasi Malaka pada abad ke-15". (Di jelaskan dalam paper yang ditulis oleh Larry Hilarian yang dipresentasikan di Hongkong pada tahun 2004, mengutip dari buku Anis Mohd N, Md, Zapin, Folk Dance of the Malay World, 2004:20). Maka bisa disimpulkan bahwa pernyataan tersebut mengatakan, banyak teori yang mengasumsikan tentang sejarah gambus melayu dan gambus hadramaut yang awal kedatangannya di Nusantara ini adalah melaui Islamisasi dari Kota Makkah pada abad ke 15.

Di Indonseia sendiri gambus merupakan musik yang berkembang pesat di era 1940-an, pada masa itu, musik gambus banyak menyedot unsur musik melayu hingga warna musik melayu tersebut begitu kuat dalam musik gambus. Beberapa Al-Munzir Vol. 12. No. 1 Mei 2019 
orkes gambus yang kemudian menjadi orkes melayu dan terkenal pada saat itu diantaranya orkes melayu (O.M.) Bukit Singuntang, O.M. Sinar Kemala, (O.M.) Kenangan, dan lain-lain. (Moh. Muttaqin, 2006:23) Setelah musik melayu berkembang kemudian musik melayu mengalami asimilasi dengan musik Arab sehingga muncullah musik gambus.

Mengenai terbentuknya grup musik Sabyan gambus, tidak lepas dari usaha salah satu personel Sabyan yakni Ahmad Fairuz sebagi leader atau yang menggawangi terkumpulnya personel kemudian membentuk grup musik. Grup musik Sabyan terbentuk tanggal 27 Januari 2015, namun pada tahun ke-3 grup ini baru memiliki formasi lengkap yang terdiri dari Nissa (penyanyi) dan Ahmad Fairuz (pemain keyboard), Sofwan Yusuf (Perkusi), Kamal (Darbuka) Tubagus Syaifulloh (Biola atau gambus) dan Anisa Rahma (Dukungan Vokal). (http://MuriaNews.Com, 25 Desember 2018). Dari sering mengisi acara wedding dan khitanan yang mempertemukan mereka, meskipun masing-masing personel memiliki grup-grup sendiri yang berbeda-beda, tapi karena mereka mempunyai visi misi yang sama dan kecintaan terhadap musik gambus, pada akhirnya memutuskan untuk membentuk sebuah grup musik gambus bernuansa religi. (http://MuriaNews.Com, 25 Desember 2018) Dengan mengcover beberapa lagu diantaranya Ya Habibal Qolbi, Rohman Ya Rohman, Ya Asyiqol, Ya Jamalu, Qomarun, Deen Assalam, Law Kana Bainanal Habib, dan Atouna El Toufoule (beri kami masa kecil) dengan jumlah viewer 120 jutaan, berkat lagu cover. (http://liputan6.com, 26 Desember 2018) Sedangkan untuk jumlah Subcriber Youtube Official Sabyan Gambus memiliki hampir 2 juta followers. (http://republika.co.id, 25 Desember 2018)

Setelah berhasil dengan lagu-lagu cover yang bisa dinikmati dan diterima di tengah-tengah masyarakat, Sabyan gambus kembali merilis single debut dari hasil ciptaan para personelnya dengan judul Ya Maulana dan kembali mendapatkan apresiasi dari banyak orang dengan jumlah 25 juta kali viewer, dalam jangka waktu 2 minggu setelah dirilis. (http://republika.co.id, 25 Desember 2018) Kemudian single ke-2 yang berjudul Allahumma Labbaik dan ke-3 adalah El Oum (Ibu) dengan penerimaan yang sangat baik pula oleh para pencinta aliran musik gambus religi dan bisa dinikmati oleh seluruh kalangan. Itulah sekilas mengenai terbentuknya grup musik Sabyan gambus dan beberapa judul-judul cover lagu serta single yang sudah rampung dirilis. Sedangkan untuk titik fokus Al-Munzir Vol. 12. No. 1 Mei 2019 
pada penelitian ini adalah mengenai pemaknaan tanda yang terdapat pada gambargambar yang divisualisasikan pada lagu Atouna El Toufoule (beri kami masa kecil), yang akan lebih lanjut untuk dibahas. Lagu Atouna El Toufoule resmi diunggah pada channel youtube Sabyan tepat pada tanggal 1 Agustus 2018 dengan lebih 11 juta viewer, (http://www.aceh.tribunnews.com, 26 Desember 2018) sebuah lagu yang didedikasikan untuk anak-anak di seluruh belahan dunia yang tidak bisa merasakan kebebasan di negaranya. Terutama anak-anak yang berada di Palestina, Suriah dan daerah Timur Tengah lainnya, yang negaranya telah dirampas. (http://liriklagukita.com, 26 Desember 2018)

Kemudian lagu ini juga bercerita tentang penderitaan yang dirasakan oleh anak-anak pada khususnya dan rakyat biasa yang berada di daerah konflik atau zona perang terutama wilayah Timur Tengah yang hingga kini masih bergejolak dan penderitaan tersebut tak kunjung berakhir, dengan lagu yang mengusung pesan sosial kemanusiaan bahwa perang tidak pernah membawa dampak yang baik. (http://lirik-lagu-dunia.blogspot.com, 26 Desember 2018) Tentang anakanak yang bertanya mengapa tidak ada dekorasi yang bagus ketika musim libur, namun akhirnya anak-anak sadar bahwa tanahnya telah hilang dan dicuri kebebasannya, tentang anak-anak yang meminta masa kecilnya dikembalikan dan mendambakan kedamaian dan ada cuplikan-cuplikan anak-anak kecil di Timur Tengah yang menjadi korban serangan di Palestina dan Suriah serta banyaknya bangunan yang hancur dan kekalutan korban juga diperlihatkan dalam video ini, dengan setting video yang digarap oleh grup musik Sabyan Gambus berlatar belakang bangunan tua, sehingga menjadi wujud perwakilan atau penggambaran kondisi kejadian sesungguhnya di Palestina dan Suriah.

Lagu yang dicover oleh grup musik Sabyan Gambus berjudul Atouna El Toufoule, sejak tahun terakhir sebenarnya sudah dipopulerkan oleh Remi Bandali yang merupakan seorang penyanyi cilik tahun 80-an berasal dari Lebanon, lahir di Tripoli Lebanon 4 Juli 1979. (http://www.Jateng.tribunnews.com, 26 Desember 2018) Sehingga dalam waktu yang sangat singkat Remi menjadi simbol dari masa kecil anak-anak yang direnggut oleh perang serta menyimbolkan anak-anak Lebanon dan orangtua mereka yang menderita, judul lagunya adalah Give Us a Chance dalam bahasa Inggris, sedangkan bahasa Arabnya Atouna El Toufoule. Remi Bandali menyanyikan lagu ini dalam tiga bahasa Inggris, Arab dan Perancis. (http://www.Jateng.tribunnews.com, 26 Desember 2018). Sehingga bisa Al-Munzir Vol. 12. No. 1 Mei 2019 
disimpulkan bahwa pada dasarnya lagu Atouna El Toufoule memang kejadian secara real yang digambarkan dan ditampilkan pada video musik tersebut, sebab ada relawan yang berada di lokasi kejadian dan mengirimkan pada tim kreatif Sabyan gambus, (http://www.aceh.tribunnews.com, 26 Desember 2018) lagu yang menceritakan sebuah penderitaan dialami oleh masyarakat Palestina dan Suriah terutama anak-anak kecil yang tidak tau apa-apa, tidak berdosa dan bahkan mereka masih memerlukan tempat bermain, belajar dan mendapatkan kasih sayang dari keluarga dan orang-orang disekitar, namun itu semua hanya menjadi harapan dan impian bagi mereka, seperti inilah sedikit penggambaran yang ada dalam video musik tersebut. Berikut adalah lirik lagu lengkap dari Atouna El Toufoule yang diambil dari situs situs Online, http://lirik-lagudunia.blogspot.com, yang diposting oleh Reza Iqbal Fauzi.

\section{Gambar 1 : Lirik lagu Atouna El Toufoule}

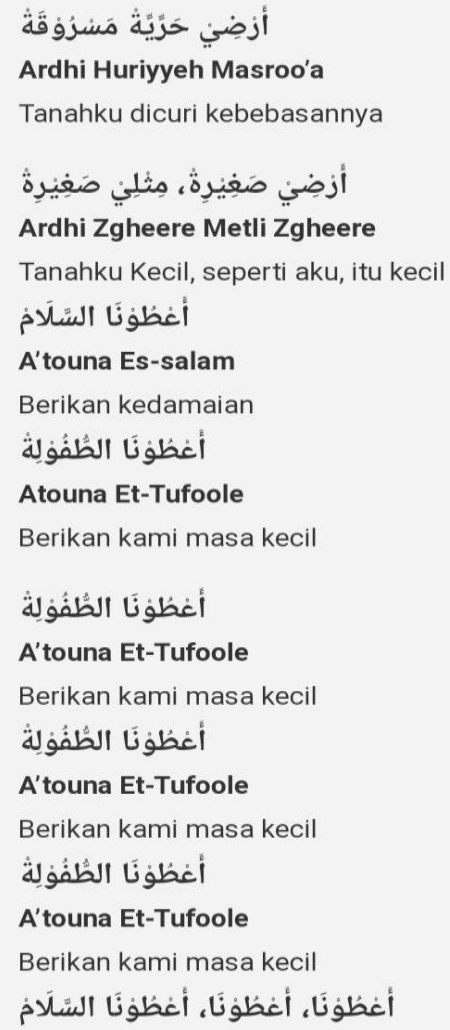

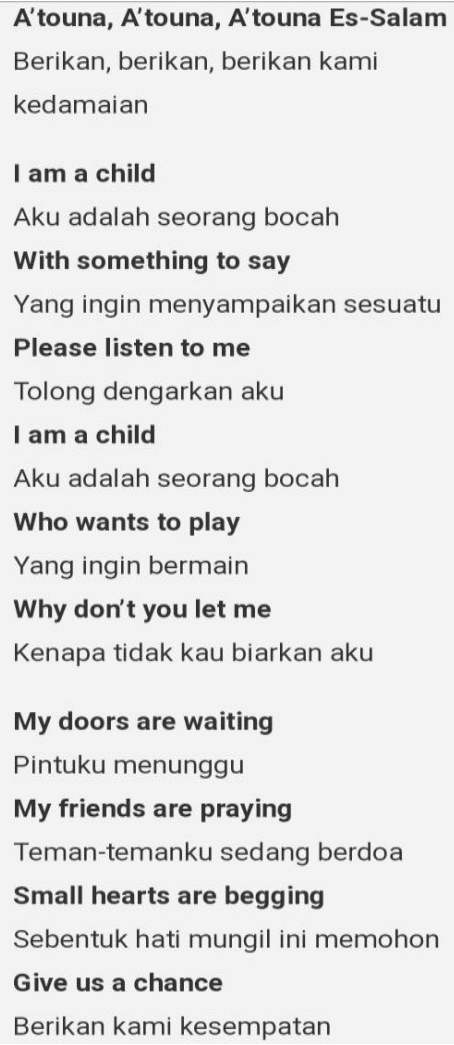


Give us a chance

Berikan kami kesempatan

Give us a chance

Berikan kami kesempatan

Give us a chance

Berikan kami kesempatan

Give us a chance

Berikan kami kesempatan

Please, please, give us a chance

Tolong, tolong, tolong berikan kami

kesempatan

أَغطوَنَا الطُفَفولِلة

A'touna Et-Tufoole

Berikan kami masa kecil

أغطونَا الطُفُوَلِة

A'touna Et-Tufoole

Berikan kami masa kecil

أغطَونَا الطُفُولِلة

A'touna Et-Tufoole

Berikan kami masa kecil

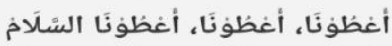

A'touna, A'touna, A'touna Es-Salam
Berikan, berikan, berikan kami

kedamaian

جِينَا نَعِيْذكُمْ

Jeena N'ayedkom

Kami datang dengan ucapan selamat berlibur

بِالِْيْيدِ مِنَسأْلْكُمْ

Bel-Eid Minsaalkum

Dan selama liburan kami tanya

kepadamu

لَيَسْ مَا فِيْ عِنَّا، لََا أَعْيَاذْ وُلَا زِيْنِهُ

Lesh Ma Fee 'Enna La 'Ayyad Wula

Zeineh

Mengapa di tempat kami tidak ada

dekorasi hari raya

\section{C.2.Analisis Semiotika Charles Sanders Peirce Pada Video Musik Atouna El Toufoule}

Sistem tanda musik adalah oditif, namun untuk mencapai pendengarnya, pengubah musik mempersembahkan kreasinya dengan perantara pemain musik dalam bentuk sistem tanda perantara tertulis, jadi visual. Bagi semiotikus musik, adanya tanda-tanda perantara, yakni musik yang dicatat dalam partitur orkestra, merupakan jalan keluar. Hal ini sangat memudahkan dalam menganalisis karya musik sebagai teks. (Alex Sobur, 2006:144) Simbolisitas dalam musik bukannya tidak ada, namun pengenalan jenis historisitas dan gaya, tergantung pada unsurunsur simbolis dalam tanda kompleks yakni karya musik. (Alex Sobur, 2006:145) Van Zoest mengatakan bahwa dalam musik terutama musik pop terdapat bidangbidang perasaan dasar, yang meliputi perasaan duka, asmara, pesona cinta, kesepian, rasa tidak dipahami dan sebagainya. (Alex Sobur, 2006:146) Meskipun dalam penelitian ini hanya akan membahas mengenai musik dengan genre gambus religi yang dilihat dari tanda-tanda yang ada pada sebuah visualisasi video musik Atouna El Toufoule, grup musik Sabyan Gambus. 
Sehingga dalam menganalisis musik tentu diperlukan ilmu disiplin lain misalnya Ethnomusicology dan antropologi. Sebagai sebuah disiplin yang populer dan memiliki metodologi yang sangat unik kemudian Ethnomusicology merupakan ilmu pengetahuan tentang musik yang relatif muda umurnya. Mantle Hood seorang pelopor Ethnomusicology sebagai studi musik dari segi sosial dan kebudayaannya. (I Made Bandem, 1981:41-43) Maka dapat disimpulkan bahwa tanda-tanda dan simbol yang digunakan untuk mendukung sebuah musik tidak terlepas dari analisis semiotika.

Semiotika atau semiotik dimunculkan pada akhir abad 19 oleh filsuf aliran pragmatik Amerika. Charles Sanders Peirce merujuk pada doktrin formal tentang tanda-tanda, yang menjadi dasar dari semiotika adalah konsep tentang tanda, tak hanya sistem bahasa komunikasi yang tersusun oleh tanda-tanda, melainkan dunia itu sendiri pun sejauh terkait dengan pikiran manusia seluruhnya terdiri atas tandatanda karena jika tidak begitu manusia tidak akan bisa menjalin hubungannya dengan realitas. (Alex Sobur, 2006:13). Bagi Pierce (Pateda, 2001:4), tanda "is something which stands to somebody for something in some respect orcapacity." Sesuatu yang digunakan agar tanda bisa berfungsi, oleh Pierce disebut ground. Konsekuensinya, tanda (sign atau representamen) selalu terdapat dalam hubungan triadik, yakni ground, object, interpretant. (Alex Sobur, 2006:146) Atas dasar hubungan ini, Pierce mengadakan klasifikasi tanda yaitu tanda yang dikaitkan dengan groud dibagi menjadi qualisign yaitu kualitas yang ada pada tanda, misalnya kata-kata kasar, keras, lemah, lembut dan merdu, sinsign yaitu eksistensi aktual benda atau peristiwa yang ada pada tanda, misalnya kata kabur dan keruh yang ada pada urutan kata air sungai keruh yang menandakan bahwa ada hujan di hulu sungai dan legisign yaitu norma yang dikandung oleh tanda, misalnya rambu-rambu lalu lintas yang menandakan hal-hal yang boleh atau tidak boleh dilakukan manusia. . (Alex Sobur, 2006:146)

Sedangkan berdasarkan objeknya, Peirce membagi tanda atas icon/ikon yaitu tanda yang hubungan antara penanda dan petandanya bersifat bersamaan bentuk alamiah, atau dengan kata lain ikon adalah hubungan antara tanda dan objek atau acuan yang bersifat kemiripan, misalnya potret dan peta, indeks adalah tanda yang menunjukkan adanya hubungan alamiah antara tanda dan petanda yang bersifat kausal atau hubungan sebab akibat, atau tanda yang langsung mengacu pada kenyataan, misalnya yang paling jelas adalah asap sebagai tanda Al-Munzir Vol. 12. No. 1 Mei 2019 
adanya api. Tanda dapat pula mengacu ke denotatum melalui konvensi. Tanda seperti itu adalah tanda konvensional yang biasa disebut simbol. Jadi simbol adalah tanda yang menunjukkan hubungan alamiah antara penanda dengan petandanya. Hubungan di antaranya bersifat arbitrer atau semena, hubungan berdasarkan konvensi (perjanjian) masyarakat. . (Alex Sobur, 2006:41-42)

Kemudian berdasarkan interpretant, tanda (sign, representamen) dibagi atas rheme yaitu tanda yang memungkinkan orang menafsirkan berdasarkan pilihan, misalnya orang yang merah matanya dapat saja menandakan bahwa orang itu baru menangis atau menderita penyakit mata atau mata dimasuki insekta atau baru bangun tidur atau ingin tidur, dicent sign atau dicisign yaitu tanda sesuai kenyataan, misalnya jika pada suatu jalan sering terjadi kecelakaan, maka di tepi jalan dipasang rambu lalu lintas yang menyatakan bahwa di situ sering terjadi kecelakaan dan argument yaitu tanda yang langsung memberikan alasan tentang sesuatu. (Alex Sobur, 2006:42)

Maka dapat disimpulkan bahwa Peirce melihat tanda (representament) sebagai bagian yang tidak terpisahkan dari objek referensinya serta pemahaman subjek atas tanda (interpretant). Adapun model triadik Peirce (representamen + objek + interpretan $=$ tanda) memperlihatkan peran besar subjek dalam proses transformasi bahasa. Seperti yang terdapat pada gambar berikut:

\section{Gambar 2: Model segitiga makna Charles Sanders Peirce}

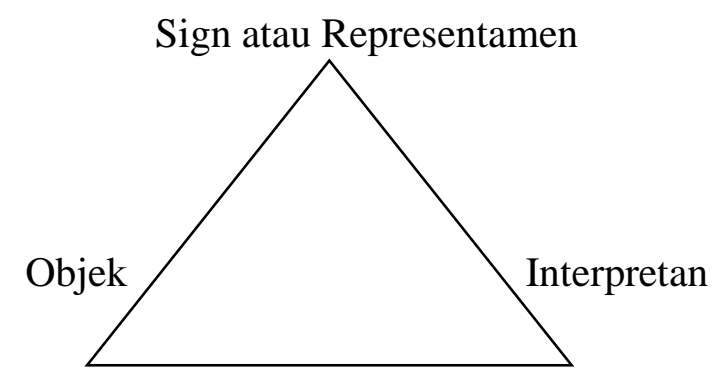

(Sumber: Yasraf Amir Piliang, Hipersemiotika: tafsir cultural studies atas matinya makna, Yogyakarta: Jalasutra, 2010)

Model triadik Peirce ini memperlihatkan tiga elemen utama pembentuk tanda, yaitu representamen (sesuatu yang merepresentasikan sesuatu yang lain), objek (sesuatu yang direpresentasikan) dan interpretant (interpretasi seseorang 
tentang tanda). (Yasraf Amir Piliang, 2010:266-267) Berdasarkan objeknya, Peirce membagi tanda atas icon (ikon), index (indeks), dan symbol (simbol). (Alex Sobur, 2006:41-42) Berikut adalah tabelnya:

Tabel 1 : Pembagian jenis tanda menurut Peirce

\begin{tabular}{|c|c|c|}
\hline $\begin{array}{l}\text { Jenis } \\
\text { Tanda }\end{array}$ & $\begin{array}{l}\text { Hubungan antara Tanda dan Sumber } \\
\text { Acuannya }\end{array}$ & Contoh \\
\hline Ikon & $\begin{array}{l}\text { Tanda yang hubungan antara penanda dan } \\
\text { petandanya bersifat bersamaan bentuk alamiah }\end{array}$ & Potret/Peta \\
\hline Indeks & $\begin{array}{l}\text { Tanda yang menunjukkan adanya hubungan } \\
\text { alamiah antara tanda dan petanda yang bersifat } \\
\text { kausal/sebab akibat }\end{array}$ & $\begin{array}{l}\text { Asap sebagai } \\
\text { Tanda adanya } \\
\text { api }\end{array}$ \\
\hline Simbol & $\begin{array}{l}\text { Tanda yang menunjukkan hubungan alamiah } \\
\text { antara penanda dengan petandanya yang } \\
\text { bersifat arbitrer/semena }\end{array}$ & $\begin{array}{l}\text { Simbol dalam } \\
\text { Perjanjian } \\
\text { masyarakat }\end{array}$ \\
\hline
\end{tabular}

(Sumber: Alex Sobur, Semiotika Komunikasi. Bandung: Remaja Rosdakarya, 2006.)

Sebagai langkah selanjutnya, peneliti akan memaparkan serta menjelaskan hasil dari analisis yang ada pada video musik Atouna El Toufoule Sabyan gambus berdasarkan analisis semiotika Charles Sanders Peirce dengan rumus model segitiga makna yaitu Sign atau Representamen, Objek dan Interpretan.

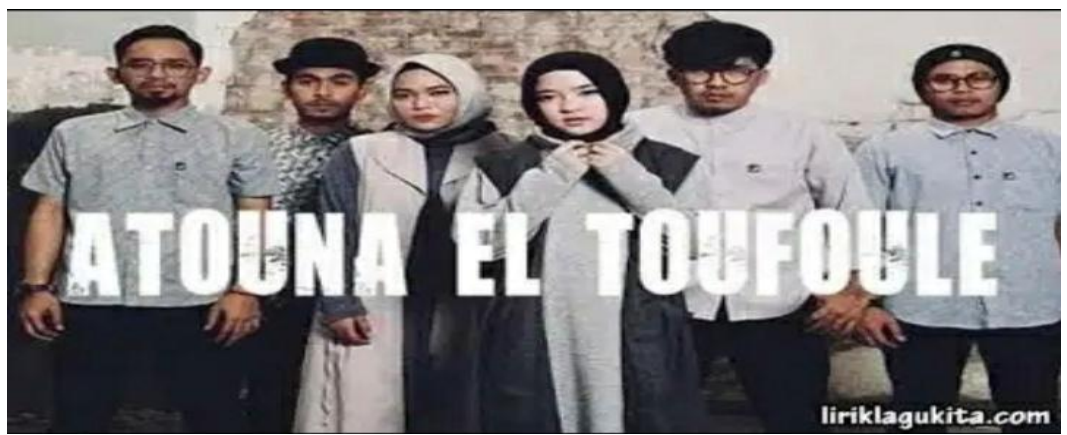

Gambar 3: grup musik Sabyan gambus pada lagu ATOUNA EL TOUFOULE Al-Munzir Vol. 12. No. 1 Mei 2019 
1. Analisis berdasarkan gambar pada durasi " 00.01 "

Gambar 4: Video Musik Atouna El Toufoule durasi “00.01

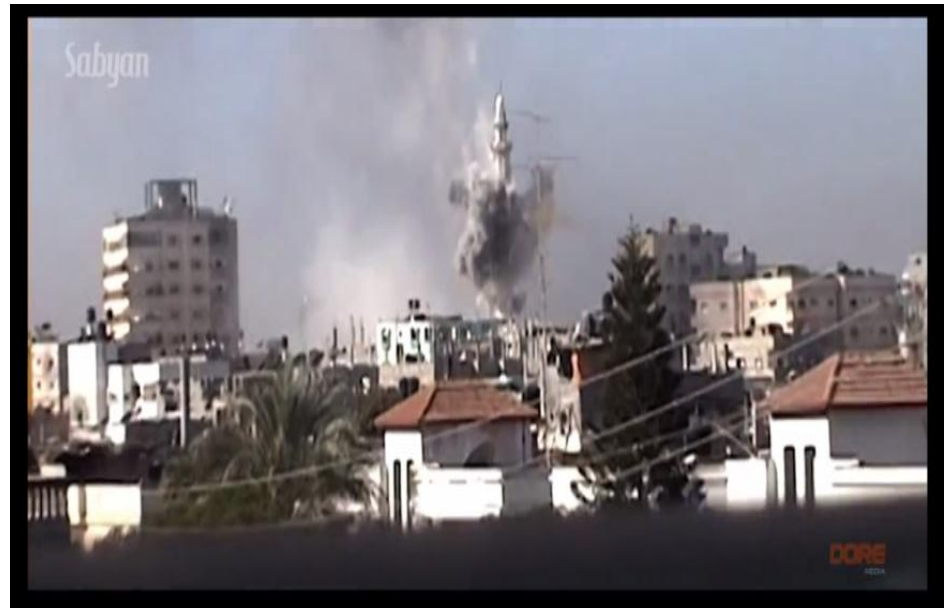

a) Sign : asap mengepul (Bom). Klasifikasi tanda berdasarkan sign berjenis sinsign.

b) Object : bangunan yang roboh atau hancur. Klarifikasi berdasarkan object berjenis indeks.

c) Interpretant : asap mengepul dikarenakan serangan bom yang diarahkan pada sutu gedung sebagai bentuk peperangan dan penindasan, yang dilancarkan oleh negara Israel kepada masyarakat Palestina untuk mengambil atau merebut dan menduduki tanah Palestina. Klarifikasi berdasarkan interpretant berjenis argument.

Pembahasan :

Pada pemaknaan dan analisis yang dilakukan di atas, maka peneliti dapat menafsirkan bahwa asap mengepul karena adanya bom dalam scene ini memiliki arti terjadinya sebuah peperangan dan penindasan yang dilancarkan oleh negara Israel kepada masyarakat Palestina. Kemudian dari pandangan ini, menimbulkan pemaknaan adanya peperangan atau kekacauan di negara bagian Timur Tengah atas perlakuan Israel yang membombardir masyarakat Palestina dengan cara yang tidak dibenarkan oleh negara karena menyangkut hidup seseorang dan hak asasi manusia.

Al-Munzir Vol. 12. No. 1 Mei 2019 
2. Analisis berdasarkan gambar pada durasi " $00.10 "$

Gambar 5: Video Musik Atouna EI Toufoule durasi “00.10"

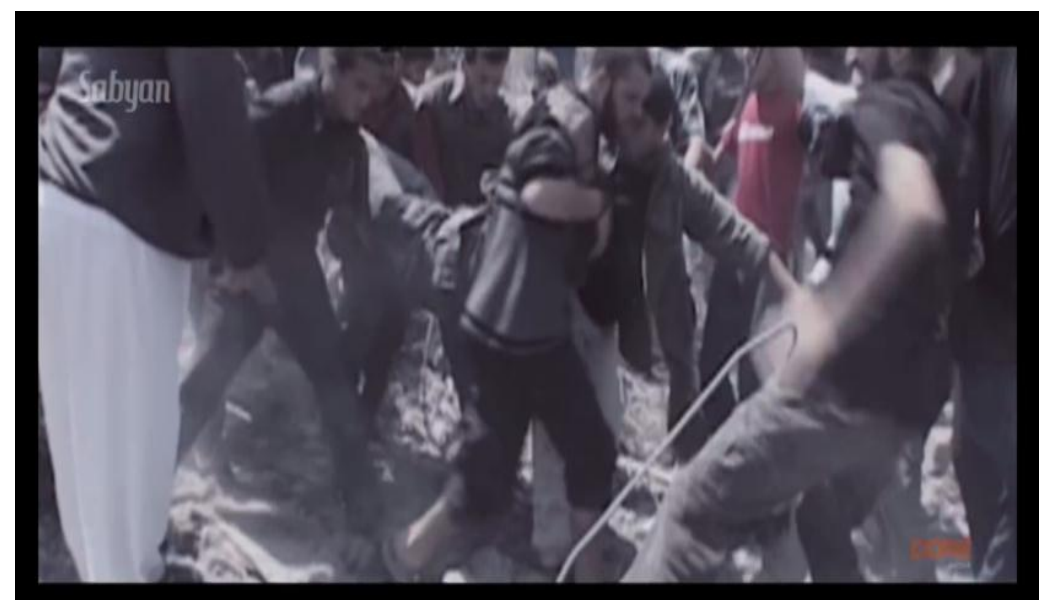

a) Sign : korban berjatuhan. Klasifikasi tanda berdasarkan sign berjenis sinsign.

b) Object : orang-orang yang mencoba membantu para korban. Klarifikasi berdasarkan object berjenis indeks.

c) Interpretant : korban manusia berjatuhan dikarenakan serangan bom yang diarahkan pada sutu gedung atau ditunjukkan kepada masyarakat Palestina, sehingga masyarakat yang selamat mencoba untuk mengevakuasi dan menolong para korban. Klarifikasi berdasarkan interpretant berjenis argument. Pembahasan :

Pada pemaknaan dan analisis yang dilakukan di atas, maka peneliti dapat menafsirkan bahwa korban manusia berjatuhan karena adanya serangan bom, dalam scene ini memiliki arti berjatuhannya korban akibat ulah Israel yang membombardir tempat tinggal masyaraka Palestina. Kemudian dari pandangan ini, menimbulkan pemaknaan adanya kekejaman dari pihak Israel yang tidak mempunyai belas kasih terhadap sesama manusia atau makhluk hidup.

3. Analisis berdasarkan gambar pada durasi " 00.12 "

a) Sign : bendera. Klasifikasi tanda berdasarkan sign berjenis sinsign.

b) Object : bendera yang yang sudah tidak sempurna dan sobek-sobek namun tetap berkibar. Klarifikasi berdasarkan object berjenis indeks. 
c) Interpretant : bendera yang terkoyak dikarenakan serangan bom yang dilakukan oleh Israel, yang menyasar untuk menghancurkan gedung, menjatuhkan korban-korban manusia dan merusak fasilitas lain seperti bendera yang dimiliki oleh negara Palestina. Klarifikasi berdasarkan interpretant berjenis argument.

\section{Gambar 6: Video Musik Atouna El Toufoule durasi “00.12”}

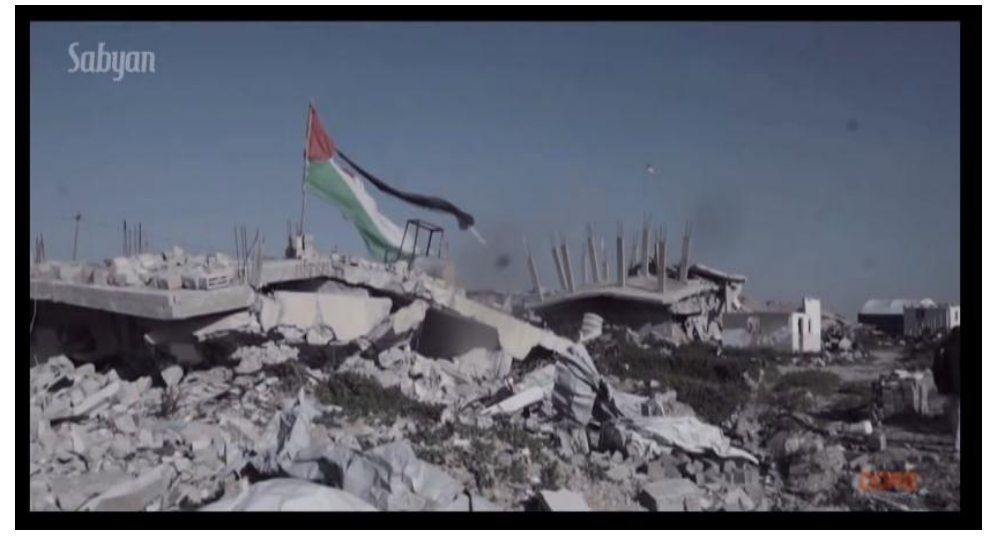

Pembahasan :

Pada pemaknaan dan analisis yang dilakukan di atas, maka peneliti dapat menafsirkan bahwa bendera yang sudah tidak utuh lagi dan gedung-gedung yang hancur dalam scene ini memiliki arti terjadinya sebuah penyerangan besar-besaran yang dilakukan negara Israel kepada masyarakat Palestina. Kemudian dari pandangan ini, menimbulkan pemaknaan adanya kehancuran dan kehilangan tempat berteduh atau tempat tinggal masyarakat Palestina, akibat ulah negara Israel yang tidak bisa dimaafkan oleh masyarakat Palestina.

4. Analisis berdasarkan gambar pada durasi " 00.27 "

Gambar 7: Video Musik Atouna EI Toufoule durasi “ 00.27 ”

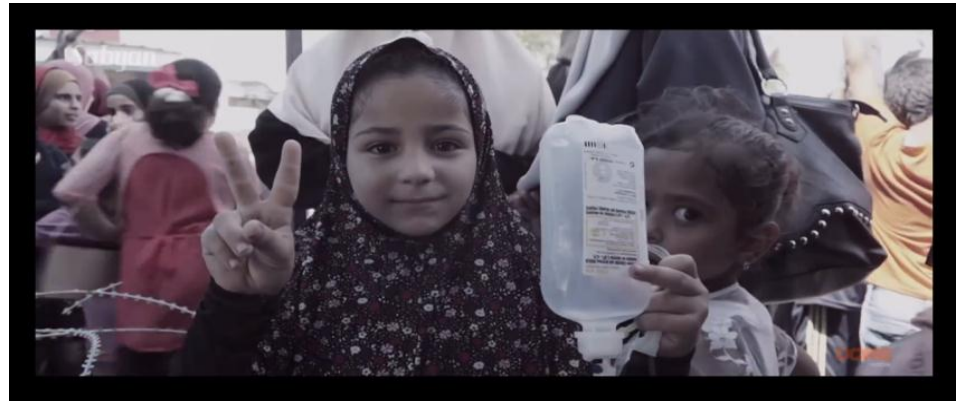

Al-Munzir Vol. 12. No. 1 Mei 2019 
a) Sign : botol infus. Klasifikasi tanda berdasarkan sign berjenis qualisign.

b) Object : anak yang memegang satu botol infuse karena menjadi salah satu korban yang terluka akibat serangan bom. Klarifikasi berdasarkan object berjenis symbol.

c) Interpretant : botol infus yang dipegang oleh seorang anak dikarenakan menjadi salah satu korban serangan bom, yang dilancarkan oleh negara Israel kepada masyarakat Palestina dengan membabi buta tanpa melihat usia dan jenis kelamin.. Klarifikasi berdasarkan interpretant berjenis dicisign.

Pembahasan :

Pada pemaknaan dan analisis yang dilakukan di atas, maka peneliti dapat menafsirkan bahwa anak-anak yang seharusnya bisa bermain dan tertawa ria, harus membawa botol infus sebagai salah satu cara untuk bertahan hidup, dalam scene ini memiliki arti anak yang menjadi korban peperangan yang dilakukan oleh negara Israel kepada masyarakat Palestina. Kemudian dari pandangan ini, menimbulkan pemaknaan adanya banyak korban yang berjatuhan tidak terkecuali anak-anak kecil.

5. Analisis berdasarkan gambar pada durasi " 01.35 "

Gambar 8: Video Musik Atouna El Toufoule durasi “00.35"

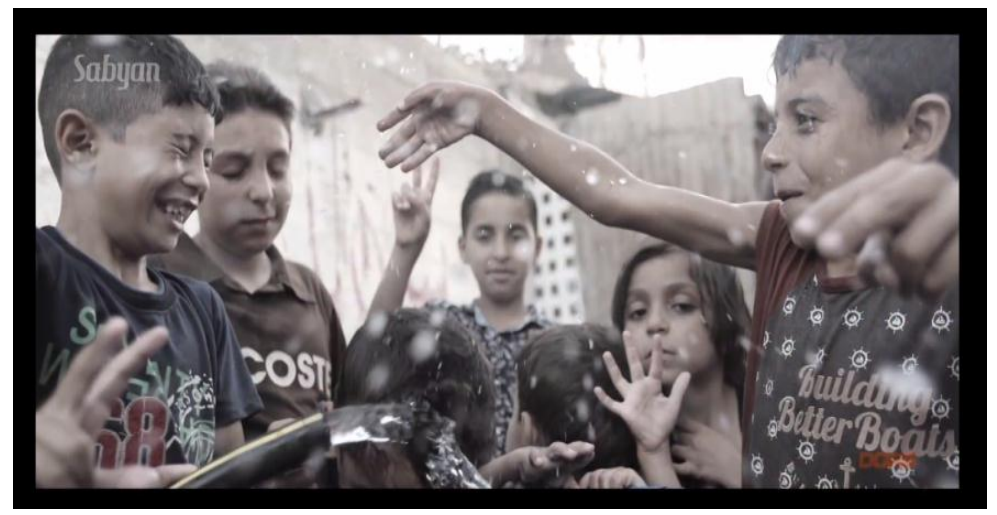

a) Sign : air. Klasifikasi tanda berdasarkan sign berjenis qualisign.

b) Object : anak-anak yang bermain air. Klarifikasi berdasarkan object berjenis indeks.

c) Interpretant : bermain air yang dilakukan oleh anak-anak Palestina bisa jadi membuat sedikit kebahagiaan di wajah mereka dan melupakan trauma serta 
tindak kekerasan dan peperangan yang terjadi di negara mereka. Klarifikasi berdasarkan interpretant berjenis rheme.

Pembahasan :

Pada pemaknaan dan analisis yang dilakukan di atas, maka peneliti dapat menafsirkan bahwa dengan bermain air yang dilakukan oleh anak-anak Palestina dalam scene ini memiliki arti kebahagiaan yang coba digambarkan pada wajah anak-anak Palestina dengan sedikit melupakan kejadian-kejadian mengerikan seperti peperangan, banyaknya korban yang berjatuhan, darah di mana-mana bahkan kelaurga mereka ada yang meninggal akibat serangan bom yang dilakukan negara Israel, yang tidak pernah dibayangkan dan tidak ingin ada dalam hidupannya. Kemudian dari pandangan ini, menimbulkan pemaknaan adanya rasa bahagia dengan bermain air.

6. Analisis berdasarkan gambar pada durasi " 01.38 "

Gambar 9: Video Musik Atouna El Toufoule durasi "01.38”

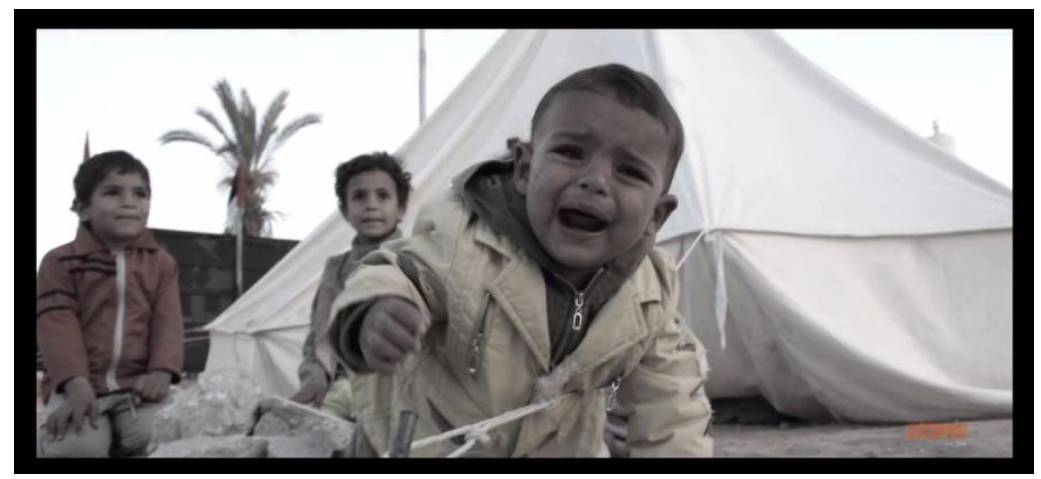

a) Sign : menangis. Klasifikasi tanda berdasarkan sign berjenis sinsign.

b) Object : anak kecil yang merangkak dan mengacungkan tangan dalam keadaan sedih, yang bisa terlihat dari wajah. Klarifikasi berdasarkan object berjenis indeks.

c) Interpretant : suasana yang mencekam dengan banyaknya bom dan korban yang berjatuhan, akibat serangan yang dilancarkan oleh pihak Israel kepada masyarakat Palestina yang menyasar kebanyakan korbannya adalah anak kecil begitupun jika mereka yang selamat tapi malah kehilangan sosok figur orang tua yang akan membesarkan dan mendidiknya, inilah kemunngkinan yang 
membuat mereka menangis dan mengalami kesedihan. Klarifikasi berdasarkan interpretant berjenis argument.

Pembahasan :

Pada pemaknaan dan analisis yang dilakukan di atas, maka peneliti dapat menafsirkan bahwa keadaan dan situasi yang membuat anak menangis dalam scene ini memiliki arti mereka menginginkan kedamaian dan kasih sayang sebagai bentuk wujud untuk kelangsungan hidup mereka yang masih membutuhkan orang tua untuk merawat dan membesarkan mereka. Hal ini terjadi akibat peperangan yang terjadi di negara Palestina. Kemudian dari pandangan ini, menimbulkan pemaknaan adanya kesedihan yang terjadi di Palestina akibat atas perlakuan Israel yang membombardir masyarakat Palestina dengan cara yang cukup kejam.

7. Analisis berdasarkan gambar pada durasi " 01.42 ”

Gambar 9 : Video Musik Atouna El Toufoule durasi “01.42”

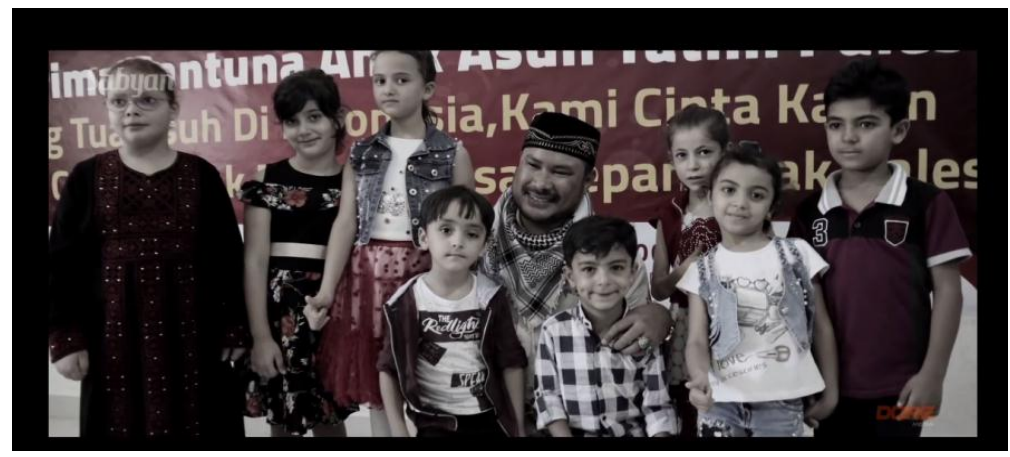

a) Sign : tangan yang memeluk. Klasifikasi tanda berdasarkan sign berjenis qualisign.

b) Object : pria dewasa yang mencoba memeluk dan merangkul untuk memberikan kasih sayang kepada anak-anak korban dari negara Palestina. Klarifikasi berdasarkan object berjenis indeks.

c) Interpretant : sebagai bentuk kasih sayang para relawan dari berbagai negara yang datang untuk memberikan sedikit kebahagiaan kepada korban-korban perang seperti anak-anak kecil adalah dengan membuat mereka tersenyum dan memberikan uluran tangan mendekap dan memberikan kenyamanan dan keamanan. Klarifikasi berdasarkan interpretant berjenis argument.

Pembahasan :

Al-Munzir Vol. 12. No. 1 Mei 2019 
Pada pemaknaan dan analisis yang dilakukan di atas, maka peneliti dapat menafsirkan bahwa dengan memberikan perlakuan baik terhadap para korban perang di Palestina salah satunya adalah memeluk dan mendekap serta memberikan senyum diwajah mereka merupakan bentuk nyata dari kepedulian dan kasih sayang sesama manusia, dalam scene ini memiliki arti adanya kasih sayang yang coba dibangun oleh para relawan untuk menghilangkan trauma dan mencoba untuk memberikan keluarga baru bagi mereka. Kemudian dari pandangan ini, menimbulkan pemaknaan adanya kedamaian dan kesejukan serta kebahagiaan yang tergambar pada wajah anak-anak kecil masyarakat Palestina.

8. Analisis berdasarkan gambar pada durasi "03.13"

Gambar 9 : Video Musik Atouna El Toufoule durasi “01.42"

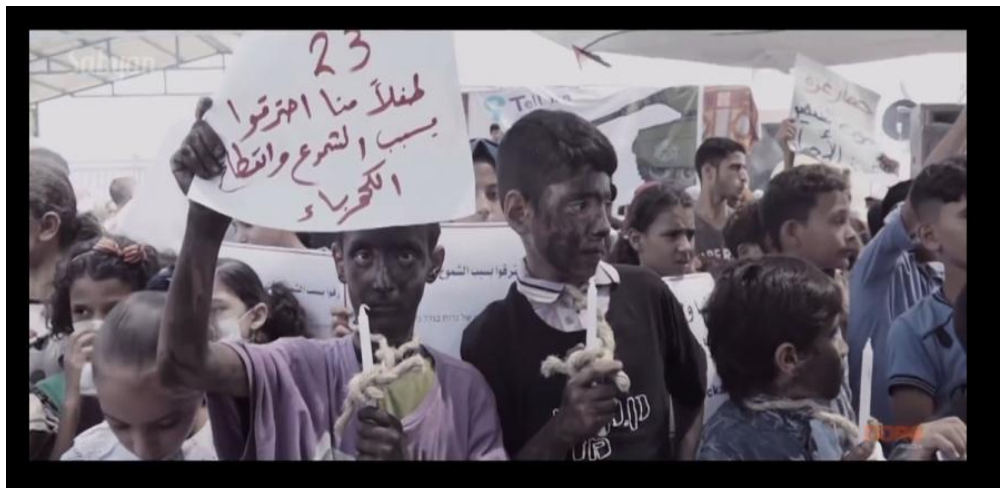

a) Sign : lilin, kertas quarto yang sudah ditulis dengan spidol dan wajah yang diwarnai dengan warna hitam. Klasifikasi tanda berdasarkan sign berjenis qualisign.

b) Object : anak-anak kecil yang coba menyuarakan pendapat. Klarifikasi berdasarkan object berjenis icon.

c) Interpretant : sebuah kertas yang dibubuhi tulisan-tulisan, dengan sebuah lilin di tangan dalam keadaan wajah diwarnai dengan warna hitam gelap yang menandakan bentuk protes dan menginginkan kedamaian serta dihentikannya peperangan yang dilakukan terhadap Palestina, sebab sudah menjatuhkan banyak korban termasuk teman dan keluarga mereka. Klarifikasi berdasarkan interpretant berjenis dicisign. 
Pembahasan :

Pada pemaknaan dan analisis yang dilakukan di atas, maka peneliti dapat menafsirkan bahwa bentuk protes yang mereka lakukan dalam scene ini memiliki arti kedamaian dan ketentraman serta kebahagian yang mereka inginkan untuk kembali ada serta terwujud di kehidupan anak-anak Palestina. Kemudian dari pandangan ini, menimbulkan pemaknaan adanya usaha yang dilakukan anak-anak Palestina dengan berkumpul dan mengadakan demo sebagai bentuk protes atas ketidak adilan yang didapatkan oleh mereka.

9. Analisis berdasarkan gambar pada durasi "04.06"

Gambar 10 : Video Musik Atouna El Toufoule durasi "04.06"

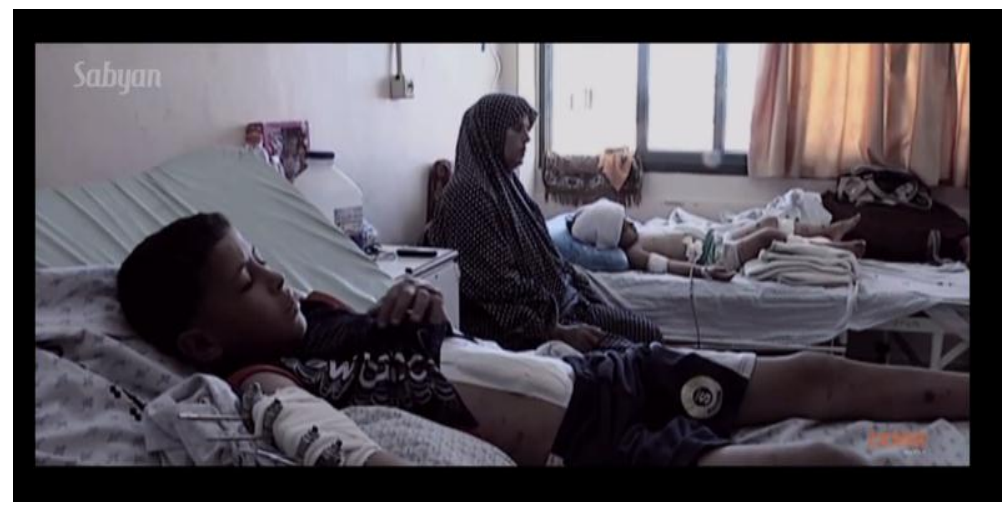

a) Sign : perban. Klasifikasi tanda berdasarkan sign berjenis sinsign.

b) Object : anak-anak yang terbaring karena luka. Klarifikasi berdasarkan object berjenis indeks.

c) Interpretant : berbaring dengan keadaan diperban akibat luka-luka yang dialami atas perlakuan negara Israel yang melakukan penyerangan dan pemboman yang tunjukkan kepada masyarakat Palestina dengan tujuan yang tidak manusiawi. Klarifikasi berdasarkan interpretant berjenis argument.

Pembahasan :

Pada pemaknaan dan analisis yang dilakukan di atas, maka peneliti dapat menafsirkan bahwa luka-luka yang dialami oleh anak-anak Palestina dalam scene ini memiliki arti adanya kekejaman yang dilakukan Israel kepada masyarakat Palestina. Kemudian dari pandangan ini, menimbulkan pemaknaan adanya ketidakberdayaan yang dirasakan oleh anak-anak kecil Palestina untuk 
mendapatkan kebahagiaan dalam menjalani kehidupan, bahkan untuk sekedar bermain dan memperingati hari-hari.

10. Analisis berdasarkan gambar pada durasi " 04.43 "

Gambar 11 : Video Musik Atouna El Toufoule durasi "04.43"

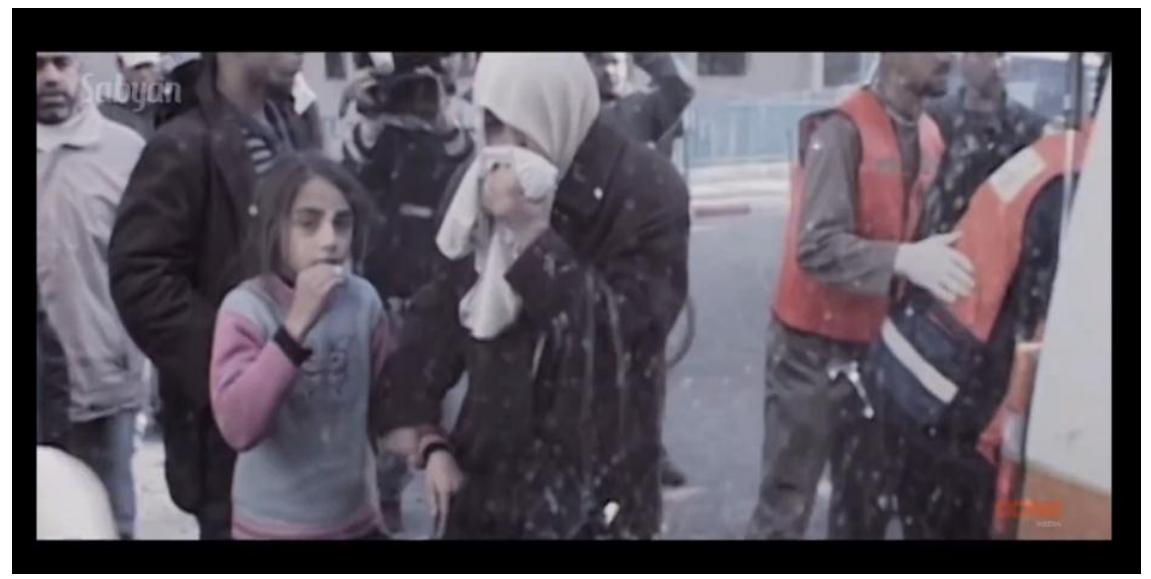

a) Sign : tim evakuasi. Klasifikasi tanda berdasarkan sign berjenis qualisign.

b) Object : menyelamatkan dan membantu para korban warga Palestina. Klarifikasi berdasarkan object berjenis indeks.

c) Interpretant : banyaknya korban yang berjatuhan membuat tim evakuasi untuk bertindak lebih sigap dalam menanggulangi situasi tersebut, sehingga korban bisa tertolong dan diselamatkan. Klarifikasi berdasarkan interpretant berjenis argument.

Pembahasan :

Pada pemaknaan dan analisis yang dilakukan di atas, maka peneliti dapat menafsirkan bahwa tim evakuasi yang datang dalam scene ini memiliki arti sebagai salah satu bentuk penyelamatan yang dialkukan untuk warga Palestina yang menjadi korban peperangan dan mengalami luka-luka yang untuk segera ditangani dan mendapatkan perawatan medis. Kemudian dari pandangan ini, menimbulkan pemaknaan adanya pertolongan yang dberikan tim evakuasi yang ikut terlibat sebagai tim penyelamat atas peperangan dan perlakuan keji yang dilakukan oleh Israel terhadap masyarakat Palestina dengan cara merobohkan bangunan dan menghilangkan nyawa serta menjatuhkan para korban. 
11. Analisis berdasarkan gambar pada durasi " 05.27 "

Gambar 9 : Video Musik Atouna El Toufoule durasi “01.42”

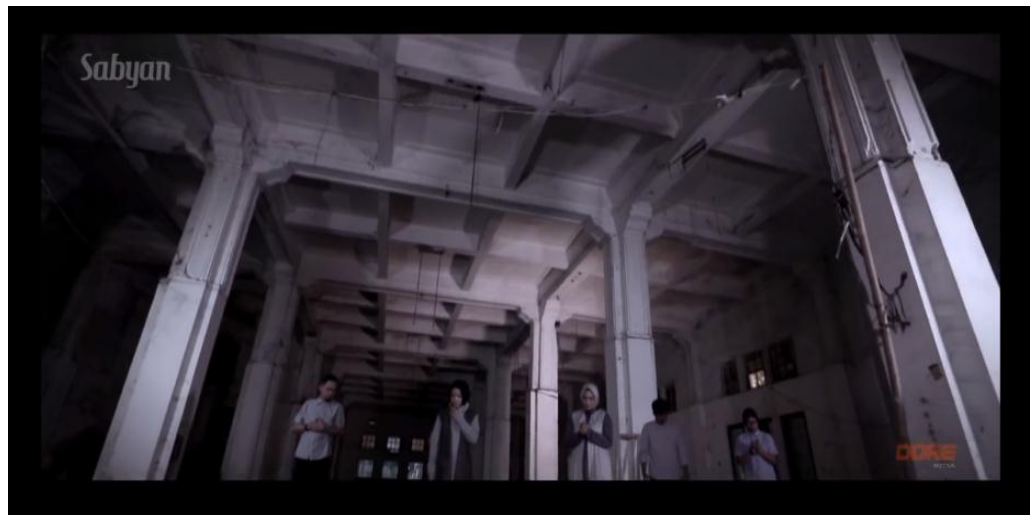

a) Sign : grup music Sabyan gambus. Klasifikasi tanda berdasarkan sign berjenis qualisign.

b) Object : bangunan tua dan gelap. Klarifikasi berdasarkan object berjenis icon.

c) Interpretant : bangunan tua dan gelap yang difungsikan sebagai latar belakang dalam video klip ini, manandakan dan mewakili kejadian yang ada di Palestina. Dunia yang sudah tidak seterang dan seindah sebelum peperangan ada dan bahkan warga Palestina kehilangan rumah-rumah mereka yang sudah rata menajadi tanah padahal itu adalah tempat untuk berkumpul dan berteduh bersama keluarga. Klarifikasi berdasarkan interpretant berjenis rheme.

Pembahasan :

Pada pemaknaan dan analisis yang dilakukan di atas, maka peneliti dapat menafsirkan bahwa latar belakang dan gedung tua yang digunakan dalam video klip ini sebagai bentuk perwakilan dan penggambaran sekilas tentang kondisi yang terjadi di Palestina, dalam scene ini memiliki arti grup musik Sabyan gambus ingin menunjukkan rasa kepedulian melalui sebuah lagu dan menyampaikan kepada masyarakat dunia bahwa masyarakat Palestina sedang mengalami peperangan dan keterpurukan dan membutuhkan uluran tangan. Kemudian dari pandangan ini, menimbulkan pemaknaan adanya keterwakilan yang coba digambarkan pada video musik Sabyan gambus dengan menggabungkan musik dengan video-video kejadian real yang terjadi di Palestina. Sehingga masyarakat bisa melihat dan memberikan doa terbaik untuk Palestina. 


\section{Penutup}

Berdasarkan pengamatan dan analisis yang dilakukan maka dapat disimpulkan bahwa video musik Sabyan gambus Atouna El Toufoule dalam beberapa scene yang ada pada video tersebut menggambarkan kejadian-kajadian real yang terjadi dikarenakan negara Israel melakukan penyerangan dan pemboman terhadap warga Palestina. Banyaknya korban yang berjatuhan diantaranya adalah anak-anak kecil yang masih menginginkan bermain bersama teman-teman sebaya dan membutuhkan kasih sayang dari para orang tua, namun mereka kehilangan masa bermain bahkan keluarga dan rumah tempat tinggal mereka.

Dari data yang diperoleh melalui sumber internet dan yang ada pada video musik Atouna El Toufoule Sabyan gambus, menunjukan bahwa media ini setidaknya bisa memberikan gambaran jelas mengenai peristiwa yang terjadi di Palestina, dengan berbagai gambar-gambar dalam video yang sudah mampu mewakili kesedihan yang dirasakan oleh masyarakat Palestina serta memiliki makna-makna yang bisa dipahami oleh masyarakat dengan cara melihat video ini. Meskipun dalam video ini hanya ingin menggambarkan kondisi-kondisi anakanak yang ada di Palestina dengan tidak menampilkan sikap atau perlakuan kekerasan secara nyata yang dilakkukan oleh negara Israel kepada Palestina.

Dengan demikian, menurut hemat peneliti, hasil penelitian ini menunjukkan bahwa nasib anak-anak di Palestina yang membutuhkan kedamaian dan kasih sayang serta kebebasan untuk bermain dan merasakan kebahagiaan lagi berkumpul bersama keluarga serta orang tua, mampu digambarkan dengan baik pada video musik Sabyan gambus yang berjudul Atouna El Toufoule.

\section{Daftar Pustaka}

Bandem, I Made 1981. Ethnomusicology Penyelamat Musik Bangsa-bangsa, Analisis Kebudayaan, Tahun II, Nomor 1. Jakarta : Departemen Pendidikan dan Kebudayaan.

Koentjaraningrat 2009. Pengantar Ilmu Antropologi. Jakarta : Rineka Cipta. Kusumawardhani, Arif 2014. Membangun Musik Indonesia Melalui Budaya Berbagi. Universitas Mercu Buana Yogayakarta : Jurnal Ilmu Komunikasi. M, Titik Oktia 2010. Ensiklopedia Alat Musik Tradisional. Surabaya : SIC. 
Piliang, Yasraf Amir 2010. Hipersemiotika: Tafsir Cultural Studies atas Matinya Makna. Yogyakarta: Jalasutra.

Sobur, Alex 2006. Analisis Teks Media Suatu Pengantar Untuk Analisis Wacana, Semiotika dan Analisis Framing. Bandung : Remaja Rosdakarya.

Sobur, Alex 2006. Semiotika Komunikasi. Bandung : PT REMAJA ROSDAKARYA

\section{Situs Online}

Hasil wawancara grup musik Sabyan gambus pada saat menjawab pertanyaan Sahabat Sabyan di Hotel Kenari Kudus, Jumat 27 Juli 2018 malam, oleh salah satu pemberitaan Online http://MuriaNews.Com, diakses pada tanggal 25 Desember 2018.

Portal berita Online, http://liputan6.com, yang diterbitkan pada 08 Juni 2018, diakses tanggal 26 Desember 2018.

Portal berita Online, http://republika.co.id, yang diterbitkan pada 07 Juni 2018, diakses tanggal 25 Desember 2018.

Portal pemberitaan Online, http://www.Jateng.tribunnews.com, yang diterbitkan pada 02 Agustus 2018 dan diakses pada 26 Desember 2018.

Situs Online pada Portal Pemberitaan http://tirto.id, diterbitkan pada 09 Juni 2018, dan diakses tanggal 25 Desember 2018

Situs Online, http://lirik-lagu-dunia.blogspot.com, yang diposting oleh Reza Iqbal Fauzi, diakses pada tanggal 26 Desember 2018.

Situs online, http://liriklagukita.com, yang diterbitkan pada 24 Juni 2018, diakses pada 26 Desember 2018.

Situs Online, pada portal pemberitaan http://www.aceh.tribunnews.com, yang diterbitkan pada tanggal 28 Agustus 2018, dan diakses pada 26 Desember 2018. 
